\author{
N.A. Prodanova, ${ }^{1}$ K.S. Mukhtarova, ${ }^{2}$ (D) G. Baikushikova, ${ }^{3}{ }^{\text {(D) }}$ K.Tursynbek ${ }^{4}$. \\ ${ }^{1}$ Plekhanov State University, Moscow, Russia \\ al-Farabi Kazakh National University, Almaty, Kazakhstan, \\ e-mail: gulnara.baikushikova@gmail.com.
}

\title{
THE ROLE OF REGIONAL COOPERATION IN ENSURING THE ENVIRONMENTAL SAFETY OF CENTRAL ASIAN COUNTRIES
}

\begin{abstract}
Issues of environmental safety and sustainable development, including land degradation and soil pollution and efforts to combat these processes, are relevant for the region. At the beginning of the 21 st century, new environmental security challenges are becoming even more relevant. A significant proportion of these challenges are global environmental problems. Security - the threat of land depletion and degradation, the huge unresolved complex water-energy problems, loss of the gene pool and biological diversity, other risks associated with ill-conceived and dangerous experiments in the field of creating new bio-environmental instruments. In these conditions, environmental safety becomes an integral part of the national security strategy of any state, and solutions environmental issues are turning into one of the core elements of any international integration association. The environmental policy of the countries of Central Asia is organized structurally and its main focus is the socio-economic and political process at the international level and within the state itself. The goal of countries' environmental safety policies is the environmental system of the environment and ensuring safety against threats that arise as a result of natural influences.
\end{abstract}

Key words: Central Asia, environmental safety, cooperation, water, sustainable development

Introduction. Issues of preserving the environment, the formation of an environment favorable for humans are among the most acute, and from about the end of the 20th century they have been characterized as one of the new challenges to humanity. In the writings of modern scholars and in discussions at scientific forums, it is often thought that, despite the fact that a lot of international environmental conventions have been adopted and modern national legislation in this area has been sufficiently developed, all this does not bring the expected result: so far environmental legislation is not so effective. In this case, I recall the words of a prominent expert in the field of international environmental law, Professor O.S, Kolbasov that environmental law should play a colossal historical role - to become a counterbalance to the rest of the law, standing guard over property wealth and its associated power.

Indeed, for thousands of years mankind enriched by natural resources has built such a system of its management, which is mainly based on the extensive consumption of natural resources and still barbaric attitude to nature. Internationally, often developed countries transfer the so-called "dirty production" to developing countries, from there they get energy sources (oil, gas, uranium), while leaving their own pantries for their efficient development by descendants. In turn, developing countries do not have the opportunity to acquire modern environmentally friendly technologies, do not have free financial resources to carry out appropriate environmental health measures, and continue to irrationally use natural resources.

As a result, environmental degradation has reached such proportions that in the modern world, since about the second half of the 20th century, special attention has been paid to solving environmental problems. This is due to the fact that, despite the difference in geographical, climatic and economic conditions, there are general environmental problems that threaten not only a single state, but also the countries of the region, and even the whole world. These include the global ones: warming (according to other statements, cooling of the climate; destruction of wildlife and, as a 
result, degradation of the earth's surface, irreversible loss of flora and fauna; disappearance of the largest water bodies (Aral) and, on the contrary, the onset of the ocean on land, etc.

Literature review. In the beginning, it should be emphasized that there is no consensus on a clear definition of environmental security. The Millennium Project of the United Nations has made five different definitions since 1996 consisting of the environmental concerns, their potential dangers and the targeted fields of protection (Zurlini and Müller, 2008, p. 1352; AC/UNU Millennium Project, No Date). The Commonwealth of Independent States (1997) defined environmental security as "the state of protection of vital interests of the individual, society, natural environment from threats resulting from anthropogenic and natural impacts on the environment". US Department of Defence (Environmental Security Report, 1996) and NATO Science Program (Science for Peace and Security Report, 1997) underlined the problems related to environmental security. Jon Barnett ('Now What?' Seminar, 1997) referred to environmental security as 'the proactive minimization of anthropogenic threats to the functional integrity of the biosphere and thus to its interdependent human component" (Zurlini \& Müller, 2008, p. 1352). Belluck, Hull, Benjamin, Alcorn and Linkov (2006, p. 3) defined environmental security as "guarding against environmental degradation in order to preserve or protect human, material, and natural resources at scales ranging from global to local". Zurlini and Müller (2008, p. 1351) stated it as "the major challenge concerns the global environmental change, focusing on the interactions between ecosystems and mankind, the effects of global environmental change on environmental degradation, the effects of increasing social request for resources, ecosystem services, and environmental goods".

According to Edward Grumbine (2018, p. 792), the term environmental security, in this sense, represents "efforts to inject interdisciplinary understanding of ecological and social concerns into international deliberations." Likewise, Zurlini and Müller (2008, p. 1354) mention environmental security as the intersection of social and ecological capitals. As it can be noticed from the abovementioned definitions, the social component of environmental security is characterized not by the state but by the human. According to Zwierlein (2018, p. 3), environmental security, hence, challenges the 'state-based' approach of traditional political sciences. However, the problem here is that the concept of security is traditionally seen as a synonym for national security and territorial integrity (Kirchner, 2015, p. 1) and therefore, attached to a set of confrontational practices associated with the state and the military (Trombetta, 2008, p. 586). The opponents, at this point, argued that the logic of security is fixed and inflexible and therefore, the linkages between the environment and security is not possible.

Material and Methods. According to Copenhagen School, security is not a fixed notion and it cannot be narrowed only to the logic of war. If a political community constructs an issue in the domain of security then it becomes a security issue and the way of dealing with it also changes. "Security in this perspective is not a value or a condition but a form of social practice" (Trombetta, 2008, p. 588). Environmental security constructs the environmental problems as severe threats to human security and all life on earth. In this construction, it highlights the notion of 'human security' as the major actor and object of security studies. For Dyer (2001, p. 442), it downplays the role of the nation-state, which was traditionally been the referent of international relations and in this context, territoriality goes out of the window. As Trombetta (2008, p. 588) adverts, environmental security constraints the legitimization of new actors and instruments to develop new forms of security governance. Brown (1977) and Wilson (1983) claims armed forces are incapable of meeting the new challenges and nation-centred realpolitik would not deliver solutions to climate change. Thus, the concept of environmental security acknowledges the need for a new definition of security above and beyond its military and state component. Attempts to redefine the concept of security resulted in the introduction of the concept 'common security' by the Independent Commission on Security and Disarmament Issues (ICSDI) in 1982.

As it can be realised, the literature goes through a discussion about the theorization of the concepts but there are gaps and uncertainties when it comes to reality: how to manage crisis and 
security when the environmental problems rigorously hit. Starting from this point, a further study in this area could potentially link a crisis scenario, sea-level rise in the Netherlands, with environmental security. To be more precise, when sea-level rises some of the territories which belong to the Netherlands could disappear. What is significant in this topic is that the main building block of national security is 'sovereignty over delineated territory' and territory lost due to sea-level rise is definitely drawing the incident under the discourse of national security. Therefore, this research would contribute to the debate about linking national security with the environment and take a side between the supporters. A potential scenario indicates that $70 \%$ of the world's coastal wetlands could be lost (Nicholls, 1999) and as Trombetta (2008, p. 12) mentions, sea-level rise is very likely to trigger large-scale migration in the long term. Examining the potential conflicts which can arise due to migration in the Netherlands would also be essential and could show pathways for stakeholders to take precautions. In this sense, the research would start with an introduction addressing the debate about considering environmental security under the realm of national security and indicate how empirical research based on the sea-level rise in the Netherlands can become an answer to this controversy. Next, it will make a literature review based on the scientific works about the detailed impacts of sea-level rise on the Netherlands, i.e. what is the worst-case scenario, which regions will disappear, who are the stakeholders, is there an action plan etc. (Kwadijk et al, 2010; Katsman et al, 2011; VanKoningsveld et al, 2008). Then, it will design a potential map of migration and clearly address which communities should be dislocated if the sea-level rise could not be prevented. Taking this as its reference point, the paper will touch upon the potential conflicts which can arise between communities especially if an external migration happens. After that, according to findings obtained from this research, the article will suggest particular measures to be taken by the officials before, during and after the crisis scenario. Finally, the paper will be ended by summarizing the findings and suggestions of this empirical research.

Results and Discussion. There are a number of regional problems that arose mainly as a result of human activities: transboundary impacts and pollution due to economic and other activities, including as a result of technical accidents; development and dissemination of environmentally hazardous technologies, development and implementation of environmentally hazardous projects; development and testing of new types of military equipment and weapons, including weapons of mass destruction; irrational use of water, including the resources of transboundary rivers and reservoirs, etc.

For Kazakhstan and the countries of Central Asia (in which, in addition to neighboring Central Asian countries, a number of politicians include Afghanistan), similar environmental problems are associated with the fact that in Soviet times the republics represented a number of complexes of industrial and agricultural production of raw materials. As a result, billions of tons of solid waste were accumulated mainly in the mining industry (in Kazakhstan alone, we now have about 22 billion tons of waste), land resources were damaged and disrupted, air pollution and both aboveground and underground water resources were damaged. The ecology of the region today, as experts say, is in a state of neglect. Therefore, the region of Central Asia is one of the most important on the whole continent, affecting the solution of modern environmental problems.

Climate change mitigation and promoting a green economy in Central Asia were the focus of the 6th High-Level Conference of the European Union-Central Asia, held January 24-25, 2019. The conference confirmed the EU's commitment to continue working in the region and contributed to the formation of future EU programs to assist Central Asian countries in the field of environment, climate change and water resources (Government of Kazakhstan. Strategy of development of Republic of Kazakhstan till 2030).

The State Committee of the Republic of Uzbekistan on Ecology and Environmental Protection emphasized the formation of a completely new atmosphere of cooperation and the observed dynamic development of regional cooperation in Central Asia, a significant strengthening of cooperation in solving priority environmental problems of the region. The need for development and practical implementation of specific projects and measures in the field of environmental 
protection, including those aimed at improving the ecological and socio-economic situation in the Aral Sea region, support of the Multi-Partner Trust Fund for Human Security for the Aral Sea Region, was noted within the framework of this EU-CA cooperation platform, strengthening regional cooperation within the framework of IFAS, water conservation and rational use of limited transboundary water resources, attracting investment It is worth noting the need for sustainable development and external financial and technical assistance for the implementation of innovative solutions for low-carbon development, reduction of environmental pollution, rational nature management, as well as conservation of biodiversity, prevention of desertification, ecosystem degradation (The EU and Central Asia determine future cooperation in the field of the environment and water resources).

In recent years, the state began to pay special attention to environmental protection in Kazakhstan. In 2013, the concept of the country's transition to a green economy was adopted, the environmental code was revised later, various green programs are being sponsored, including garbage collection, recycling projects, etc. But, despite all these positive undertakings, it's very early to talk about the fact that there has been a shift in the general population towards the formation of environmental awareness, and it's too early to talk about the growing involvement of the majority of the population in protecting the environment (Consolidated analytical report on the state and use of lands of the Republic of Kazakhstan for 2017).

In Central Asia, climate change will put additional pressure on water, agriculture and energy and are likely to have consequences for individual countries, as well as for the region as a whole.

Water is the main natural resource in the region, and water availability is a priority, especially in the case of transboundary water resources. In the medium term (2030-2050) population growth and economic development probably will lead to increased demand for water and land resources in Central Asia. Change forecasts climate and water needs indicate a sufficient supply of water for the next 10-15 years. However, between 2030 and 2050 is expected to the region will see a peak in water availability in many medium and small rivers in inland and southern areas. In the long run, one of the main factors conditional well-being and prosperity will the rate of climate change and the severity of its effects, combined with the dynamics of changes in numbers population, socioeconomic status and freedom of movement (On approval of the Action Plan for the implementation of the State Program for Water Resources Management of Kazakhstan for 2014 - 2020).

Mountain areas are particularly vulnerable to climate change, where melting glaciers and permafrost disrupt water regimes and endanger ecosystems, where natural disasters are becoming more common and devastating, which affects quality of life of the population. In arid and low-water competition over pastures and local ones will intensify over the years water resources, which can lead to tension. Constant attention is required by the situation in the mountains and densely populated areas as well as the southern borders Central Asia.

All countries in the region have developed national climate change strategies and action plans. to move towards low emissions development carbon, and also launched projects mitigation and adaptation to infrared. Regarding climate change mitigation, in 2015 Kazakhstan, Kyrgyzstan, Tajikistan and Turkmenistan submitted their preliminary national contributions provided by the Framework United Nations Climate Change Convention, and through this raised discussion climate change issues at the highest political level (The strategic development plan of the Republic of Kazakhstan until 2025).

Another urgent regional security issue is associated with proliferation risks biological weapons. Formally, a convention on the prohibition of biological and toxic weapons, to which the United States and the USSR joined, it was adopted back in 1972. However, its implementation in practice is hindered by the lack of verification mechanism and mutual checks. In 2001, Russia proposed such a mechanism, having developed with other countries relevant protocol. But the US came out of negotiations and began to form around the world a closed system of military biological objects.

General environmental and economic problems of a single natural region, also understanding the importance of a strategic approach and coordination of efforts to achieve regional environmental 
stability, necessitated the adoption of joint and concerted action from all countries of Central Asia. Cooperation on ensuring environmental safety in the region Central Asia is reflected in a number of joint regional programs and initiatives developed at base of multilateral agreements (Zhakenov, M. (2014), Parshina, G., Mukiyanova, U., Shabanova, L. (2012), Kanchan, K., et al. (2015)).

Today, there are several joint political declarations adopted by guidelines of the countries of Central Asia and Russia, defining fundamental principles regional cooperation in the field of environmental safety and sustainable development. Among them are the following: Almaty Declaration of the Presidents of Central Asia, 1997; Tashkent Declaration of the UN Special Program for Central Asia, 1998; Dushanbe Declaration, 2002 (Ecological portal "Environment and Sustainable Development in Central Asia and Russia (CARNet). Given the interdependence of ecosystems in Central Asia and the risk of emergencies, consequences which cannot be eliminated by one country, the Republic of Kazakhstan, the Kyrgyz Republic, The Republic of Tajikistan, the Republic of Turkmenistan concluded in 1997 an agreement on cooperation in areas of prevention and mitigation of emergency situations.

Nevertheless, all of them formed the basis of the Central Asian Climate Change Conference (CACCC-2019), which is currently taking place in Tashkent. This conference was a continuation of the World Bank's initiative on the exchange of knowledge and information on climate change in Central Asia, supported by the "Program on Adaptation to Climate Change and Mitigation of Its Implications for the Aral Sea Basin" (CAMP4ASB project). The first conference within the framework of the mentioned project was held on January 24-25, 2018 in Almaty, Kazakhstan. This year, CACCC gathered 400 representatives of government agencies, the scientific community, youth, international and regional partners, multilateral development banks and civil society organizations that work in the field of climate change.

It is worth noting that the Tajik leadership has achieved particular success in the issue of rational use of water resources. On March 22, 2018, Emomali Rahmon during the meeting of the UN General Assembly lobbied for the implementation of the fourth global initiative in the field of water resources - "The International Decade for Action "Water for Sustainable Development, 2018 - 2028" (CACCC-2019: a review of pre-conference events).

The experience of previous decades has convincingly shown that the probability of an isolated solution to the environmental problems of Central Asia without taking into account the position of neighbors in the region is practically zero. Environmental safety issues are directly related to ensuring the overall security of the region and require the collective efforts of all states. An example of such close cooperation, in addition to the aforementioned CACCC and IFAS, is the Shanghai Cooperation Organization. Expert meetings of the ministries and departments of the SCO member states responsible for environmental issues have been held since 2005. Their main goal is to prepare proposals for expanding multilateral cooperation in the framework of the implementation of the SCO's Multilateral Trade and Economic Cooperation Program, as well as improving the legal framework of the Organization (The SCO agreed on the Concept of cooperation in the field of environmental protection)

During the last meeting of experts of the ministries and departments of the SCO member states responsible for environmental protection in April 2018, a draft Concept of Cooperation in the field of environmental protection of the SCO member states was agreed in Beijing. This concept implies multilateral cooperation in the field of environmental protection of the Member States of the Organization in order to preserve and restore biodiversity for the benefit of future generations (New prospects for cooperation between Central Asia and the EU in the field of environmental protection).

Conclusion. However, experts say that our country, even with such a development of events, can get out of the predicament. The fact is that we ourselves must move from the extensive development of water, in which volumes only increase, to its economical, rational use. It is necessary to apply drip irrigation technologies, use special irrigation devices, run pipes, search for 
drinking water in the localities and abandon some costly and ineffective canal breaking programs, including turning Siberian rivers into Kazakhstan.

If we talk about the region, many environmental programs cannot be implemented not so much from a lack of funding, although this is also important, but from political considerations, which are often justified by environmental safety issues. But the task of preserving the ecology and life itself on earth strongly dictates the search for a compromise in the political sphere.

The analysis shows that in this area, bilateral agreements are most effective when states solve a number of interrelated problems related not only to the environment. Thus, it can be noted that states can nevertheless combine their efforts in order to develop, adopt and strictly implement a single environmental policy in the region. This requires a common development plan, a common (co-financing) and effective supranational mechanisms for its implementation, like the recently created Customs Union and the mechanisms of supranational regulation and the formation of supranational law created in it.

\section{References}

CACCC-2019: a review of pre-conference events // https: // carececo. Org / main / news / news /CACCC2019-4/ Consolidated analytical report on the state and use of lands of the Republic of Kazakhstan for 2017 // http://mgov.kz/wp-content/uploads/2018/avgust/25.08/kuzrotchet.pdf.

Ecological portal "Environment and Sustainable Development in Central Asia and Russia (CARNet)". [Electronic resource]: Access mode: URL: http://www.caresd.net (access date: 12/20/2019).

Government of Kazakhstan. Strategy of development of Republic of Kazakhstan till 2030 // https://www.akorda.kz/en/official_documents/strategies_and_programs

Kanchan, K., et al. (2015), A Review on Air Quality Indexing System. Asian Journal of Atmospheric Environment, pp. 101-113.

New prospects for cooperation between Central Asia and the EU in the field of environmental protection and water resources are identified // http://mfa.gov.kz/ru/content-view/opredelenynovye-perspektivy-sotrudnicestva-centralnoj-azii-i- es-v-oblasti-ohrany-okruzausej-sredy-i-vodnyhresursov

On approval of the Action Plan for the implementation of the State Program for Water Resources Management of Kazakhstan for 2014 - 2020. Decree of the Government of the Republic of Kazakhstan dated May 5, 2014 No. 457 // https://egov.kz/cms/ru/law/list/P1400000457

Parshina, G., Mukiyanova, U., Shabanova, L. (2012), Conservation and management of biodiversity in the Republic of Kazakhstan: problems and challenges. Bulletin of KazNU. Biological Series. No. 2 (54). 2012, p. 16-20

The EU and Central Asia determine future cooperation in the field of the environment and water resources // http://ecogosfond.kz/wp-content/uploads/2019/04/210.pdf

The SCO agreed on the Concept of cooperation in the field of environmental protection // http://rus.sectsco.org/news/20180418/407215.html

The strategic development plan of the Republic of Kazakhstan until 2025, approved by Decree of the President of the Republic of Kazakhstan dated February 15, 2018 No. 636 // https://online.zakon.kz/document/?doc_id=38490966

UN, UNECE, ESCAP, and OSCE. The Commission of the Republic of Kazakhstan and the Kyrgyz Republic on the Use of Water Management Facilities of Intergovernmental Status on the River Chu and Talas. 2006 // https://www.unece.org/env/water/centralasia/chutalas.html

Zhakenov, M. (2014), Presentation: State Water Management Program and Kazakhstan's transition to a green economy.

Н.А. Проданова, ${ }^{1}$ Г. Байкушикова, ${ }^{2}$ Қ.С. Мұхтарова, ${ }^{3}$ К.Тұрсынбек ${ }^{4}$. 
${ }^{1}$ Плеханов экономика университетінің профессоры (Мәскеу, Ресей)

2 Әл-Фараби атындағы ҚазҰУ, Алматы, Қазақстан, e-mail: gulnara.baikushikova@gmail.com.

\title{
ОРТАЛЫК АЗИЯ МЕМЛЕКЕТТЕРІНІН ЭКОЛОГИЯЛЫҚ ҚАУІПСІЗДІКТІ ҚАМТАМАСЫЗ ЕТУДЕГІ АЙМАҚТЫҚ ЫНТЫМАҚТАСТЫҚТЫН РӨЛІ
}

\begin{abstract}
Андатпа.Қазіргі кезеңде әлемнің көптеген мемлекеттерінде экологиялық жағдайды сәтсіз деп сипаттауға болады. XXI ғасырда экологиялық қауіпсіздіктің жаңа сын-тегеуріндері өзекті тақырыпқа айналып отыр. Жағымсыз экологиялық ықпал мемлекеттік шекараларды мойындамай және тіршілік ортасына сонымен қатар, іргелес жерлерде өмір сүретін көп мөлшердегі адамдардың өмір сүру сапасына жағымсыз әсерін тигізеді. Экологиялық мәселелер көп жағдайларда аймақтық, көбінесе жаһандық сипатқа ие, тиісінше олардың шешімі бойынша қабылданатын шаралар барлық ортақ мемлекеттердің келісілген нақты саясатын талап ететін интернационалды болуы қажет, және де ең бастысы, шешім қабылдаудың ұлттық деңгейінде қабылданатын жауапкершілікті бөлісуге дайындықты талап етеді. Бұл жағдайларда экологиялық қауіпсіздік кез келген мемлекеттің ұлттық қауіпсіздік стратегиясының құрамдас бөлігі, ал оны шешу жолдары кез келген халықаралық интеграциялық бірлесуінің элементіне айналады. Экологиялық саясат Орталық Азия мемлекеттерінің қызметінің маңызды, жеке, құрылымдық жағынан ұйымдасқан, халықаралық деңгейдегі және мемлекеттің өз ішіндегі әлеуметтік-экономикалық және саяси үдеріспен тығыз байланысты бағыты болып отыр. Экологиялық қауіпсіздік саласындағы мемлекеттік саясаттың мақсаты - табиғи жүйелерді қоршаған ортаға антропогендік және табиғи әсердің нәтижесінде пайда болатын қауіптерден қорғауды қамтамасыз ету болып табылады.
\end{abstract}

Түйін сөздер:Орталық Азия, экологиялық қауіпсіздік, ынтымақтастық, су мәселесі, тұрақты даму

\footnotetext{
Н.А. Проданова, ${ }^{1}$ К.С. Мухтарова, ${ }^{2}$ Г. Байкушикова, ${ }^{3}$ К. Турсынбек ${ }^{4}$

${ }^{1}$ Плехановский экономический университет, Москва, Российская Федерация

2 Казахский Национальный Университет имени аль-Фараби, Алматы, Казахстан, e-mail: gulnara.baikushikova@gmail.com.
}

\section{РОЛЬ РЕГИОНАЛЬНОГО СОТРУДНИЧЕСТВА В ОБЕСПЕЧЕНИИ ЭКОЛОГИЧЕСКОЙ БЕЗОПАСНОСТИ СТРАН ЦЕНТРАЛЬНОЙ АЗИИ}

Аннотация. Вопросы экологической безопасности и устойчивого развития, в том числе деградации земель и загрязнения почвы и усилий по борьбе с этими процессами, являются актуальнейшими для региона. В начале XXI века новые вызовы экологической безопасности становятся еще более актуальными. Значительную долю этих вызовов составляют проблемы глобальной экологической безопасности - угроза истощения и деградации земельных ресурсов, нерешенность громадного комплекса водно-энергетических проблем, утрата генофонда и биологического разнообразия, иные риски, связанные с непродуманными и опасными экспериментами в области создания новых инструментов биовоздействия на окружающую среду. В этих условиях экологическая безопасность становится составной частью стратегии национальной безопасности любого государства, а пути решения экологических проблем превращаются в один из стержневых элементов любого международного интеграционного объединения. Экологическая политика стран Центральной Азии организован структурно и его основным направлением является социально- 
экономический и политический процесс на международном уровне и внутри самого государтсва. Цель политики стран в сфере экологической безопасности является эко системы окружающей среды и обеспечение безопасности от угроз которые появляются в результате от природных влияний.

Ключевые слова: Центральная Азия, экологическая безопасность, сотрудничество, вода, устойчивое развитие 